\title{
Appearance of a functional insulin receptor during rabbit embryogenesis
}

\author{
J.F.Peyron, M. Samson, E.Van Obberghen, D. Brandenburg and M. Fehlmann \\ INSERM U 145, Faculté de Médecine (Pasteur), Nice, France and Deutsches Wollforschungsinstitut, Aachen, FRG
}

\begin{abstract}
Summary. The domain structure of the insulin receptor was investigated in liver and brown adipose tissue of developing rabbits. The structure of the binding domain ( $\alpha$-subunit) was analysed after covalent labelling with a ${ }^{125} I$ photo-reactive insulin analogue. The structure of the tyrosine kinase domain ( $\beta$-subunit) and the transmission of the hormonal signal from the $\alpha$-to the $\beta$-subunit were analysed by stimulating with insulin the autophosphorylation of the $\beta$-subunit. Finally, the im-
\end{abstract}

munoreactivity of the receptor in developing tissues was assessed with anti-receptor antibodies. The results show that a functional insulin receptor can be detected at the early stages of fetal development in both tissues and is conserved throughout ontogenesis to adulthood.

Key words: Insulin receptor, ontogenesis, photoreactive labelling, tyrosine kinase, anti-receptor antibodies, rabbit.
Although many peptide hormones are found in fetal tissues at early stages of development [1], there is an important fluctuation in the extent of specific hormone receptors expressed by these tissues [2-5]. There is now considerable evidence that insulin plays a major metabolic and growth-promoting role during fetal life [6, 7]. Correspondingly, insulin binding sites have been found in different fetal tissues [2,4,8-11], but the degree of insulin binding differs markedly during embryogenesis, reaching a maximum in late fetal and early neonatal life $[4,8,10,11]$. All studies reported to date have aimed at analysing the maturation of insulin receptors during ontogenesis, using binding of insulin to investigate the presence and the properties of the receptors. The conclusion of these studies is that fetal insulin receptors display similar insulin binding characteristics compared with adult receptors [9-11], but by contrast to the latter, cannot be down-regulated by high ambient insulin concentration [9]. Thus, no information is available on the molecular structure of the embryonic insulin receptor.

In adult tissues the insulin receptor is composed of two types of subunits: the $\alpha$-subunit $(130 \mathrm{kDa})$ containing the insulin binding site [12-14], and the $\beta$-subunit $(95 \mathrm{kDa})$ containing a tyrosine-kinase activity, capable of self-phosphorylation reactions $[15,16]$. The aim of the present study was to characterize the molecular structure of fetal insulin receptors by investigating their three different functional domains: the insulin binding site, the kinase activity and the immunoreactive site.

\section{Material and methods}

\section{Material}

The photoreactive insulin analogue $B_{29}$ (2-nitro-4-azidophenylacetyl) insulin was iodinated to a specific activity of $200-250 \mu \mathrm{Ci} / \mu \mathrm{g}$ by using chloramine $\mathrm{T}$. Porcine monocomponent insulin was generously supplied by the Novo Research Institute (Copenhagen, Denmark). Triton X-100, phenylmethylsulphonyl fluoride (PMSF), bovine serum albumin (fraction V), bacitracin were from Sigma (St. Louis, Mo). All reagents for SDS-PAGE (polyacrylamide gel analysis) were purchased from Biorad Laboratories (Richemond, Calif). Adenosine $5^{\prime}-\left[\gamma_{-}{ }^{32} \mathrm{P}\right]$ triphosphate, triethylammonium salt (aqueous solution, $5000 \mathrm{Ci} / \mathrm{mmol}$ ) was from the Radiochemical Centre (Amersham, UK).

\section{Animals and samples}

New Zealand rabbits with a gestational period of 31 days were killed on days 20,25 and 30 postcoitum. The fetuses were removed by Caesarean section. Term fetuses were born spontaneously. All fetuses were killed by decapitation. The liver and the brown adipose tissue from the interscapular region were rapidly removed. Tissues of the fetuses of one mother were pooled and placed in five volumes of icecold saline solution (Hepes $50 \mathrm{mmol} / 1, \mathrm{NaCl} 150 \mathrm{mmol} / 1 \mathrm{pH} 7.6$ ) containing protease inhibitors $(1 \mathrm{mmol} / \mathrm{l}$ bacitracin, $1000 \mathrm{U} / \mathrm{ml}$ aprotinin and $1 \mathrm{mmol} / 1 \mathrm{PMSF}$ ). Tissues were homogenised (Polytron, Luzern, Switzerland) and kept on ice before solubilisation or photoaffinity labelling.

\section{Photoaffinity labelling of insulin receptors}

The homogenised tissues were diluted 10 times in $\mathrm{NaCl}(30 \mathrm{mmol} / 1)$, Hepes $(30 \mathrm{mmol} / \mathrm{l})(\mathrm{pH} 7.6)$ containing protease inhibitors as indicated above and incubated with ${ }^{125} I$-labelled $B_{29}$-Napa-insulin [17] $\left(10^{-8} \mathrm{~mol} / \mathrm{l}\right.$ final concentration) for $2 \mathrm{~h}$ at $15^{\circ} \mathrm{C}$ in the dark. 


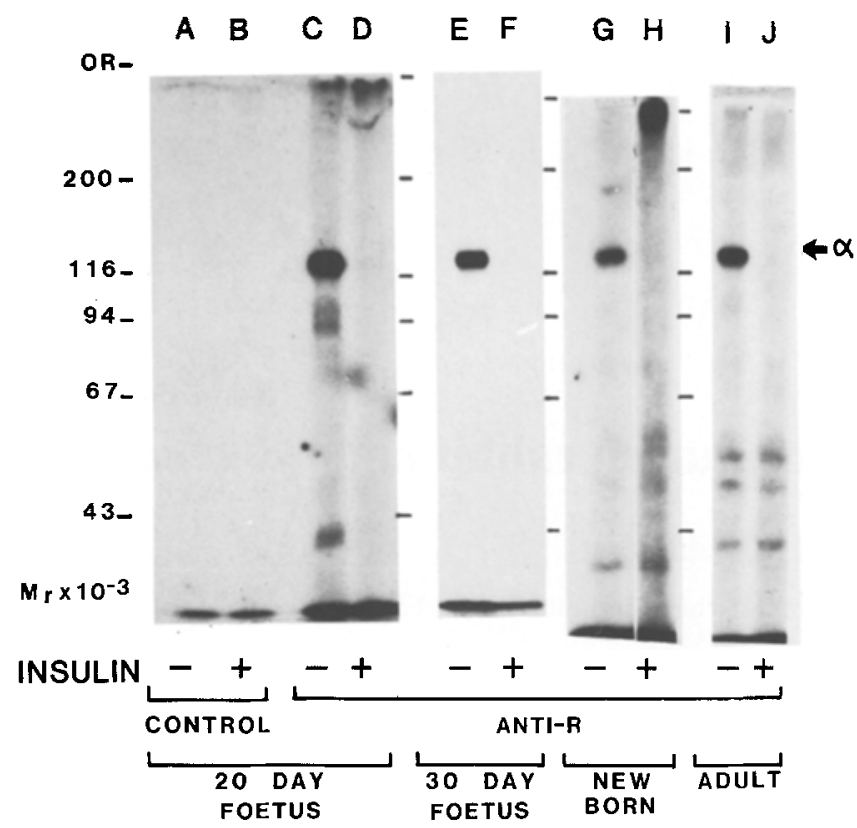

Fig. 1. Immunoprecipitation of photolabelled insulin receptors from livers of developing rabbits. Livers from 20 day-old (A-D) and 30 day-old $(E, F)$ fetuses, new born $(G, H)$ and adult $(I, J)$ rabbits were extracted and homogenised. Insulin receptors were photolabelled in the absence (lanes A, C, E, G, I) or presence (lanes B, D, F, H, J) of $1 \mu \mathrm{mol} / 1$ unlabelled insulin and solubilised in $1 \%$ Triton $X-100$. Solubilised receptors were then incubated with a control serum (control, lanes $\mathrm{A}$ and $\mathrm{B}$ ) at a 1: 150 dilution, or with a serum containing antibodies against the insulin receptor (Anti-R: $\mathrm{C}-\mathrm{J}$ ) at a 1:300 dilution. After addition of protein $\mathrm{A}$, the immunoprecipitates were solubilised in boiling SDS and analyzed by SDS-PAGE under reducing conditions followed by autoradiography. The arrow indicates the $\alpha$-subunit of the insulin receptor

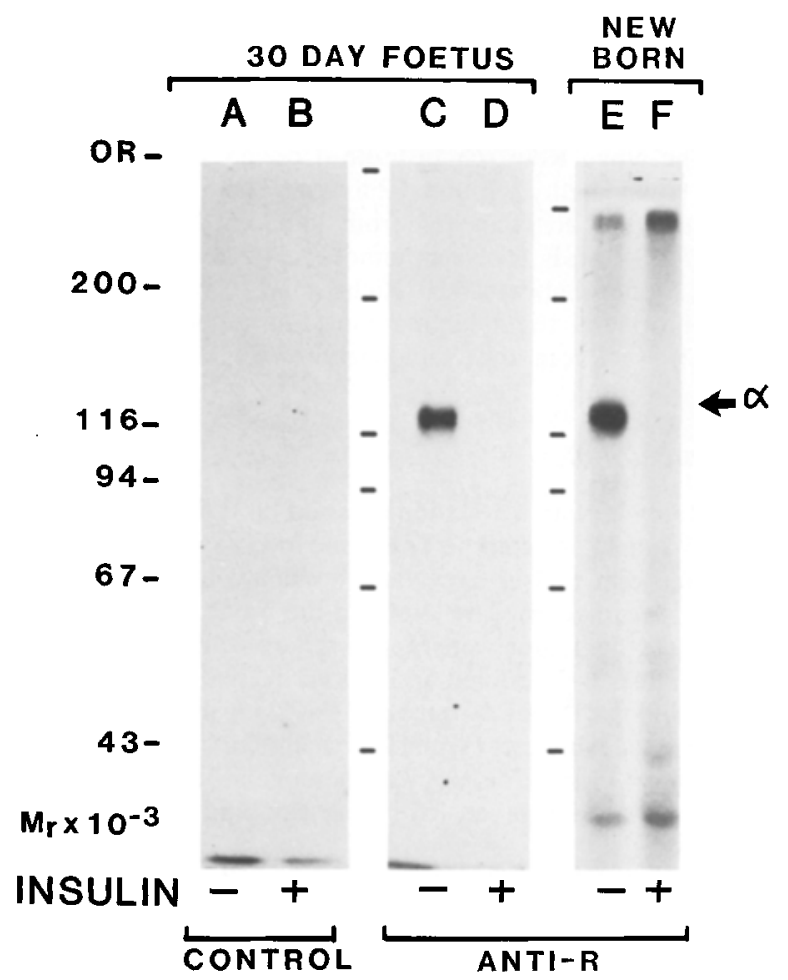

Fig. 2. Immunoprecipitation of photolabelled insulin receptors from brown adipose tissue of developing rabbits. Experimental conditions are identical to those described in the legend of Figure 1
Thereafter, photoactivation was induced by ultraviolet-irradiation $\left(330 \mathrm{~nm}, 5 \mathrm{~min}\right.$ at $\left.4^{\circ} \mathrm{C}\right)$ produced by a high-pressure mercury lamp (Philips HPK, $125 \mathrm{~W} / \mathrm{L}$ ). The homogenates were then centrifuged $(5 \mathrm{~min}$ at $18,000 \mathrm{~g})$ and washed with Hepes $30 \mathrm{mmol} / \mathrm{l}, \mathrm{NaCl}$ $30 \mathrm{mmol} / 1$ to remove unbound insulin, and solubilised either directly in boiling sodium dodecylsulfate (SDS) (for direct analysis) or in 1\% Triton X-100 for $90 \mathrm{~min}$ at $4^{\circ} \mathrm{C}$ under continuous stirring (for subsequent immunoprecipitation).

\section{Partial purification of insulin receptors}

Homogenates were solubilised in 1\% Triton X-100 as indicated above. The unsolubilised material was removed by centrifugation $(90 \mathrm{~min}$ at $100,000 \mathrm{~g}$ ) and the supernatant applied on a wheat-germ agglutininagarose column [16]. Bound glycoproteins were recovered by elution with $\mathrm{N}$-acetylglucosamine $0.3 \mathrm{~mol} / 1$. This procedure allows a 20 -fold purification of insulin receptors in adult rat liver [16].

\section{Phosphorylation assay}

The phosphorylation reaction was performed with the partially purified receptor preparation (wheat-germ agglutinin-agarose column eluate, $1 \mathrm{mg} / \mathrm{ml}$ protein). The reaction was initiated by addition of [ $\left.\gamma^{-32} \mathrm{P}\right]$ ATP $(15 \mu \mathrm{mol} / 1$ final concentration $), \mathrm{MnCl}_{2}(4 \mathrm{mmol} / \mathrm{l})$ and $\mathrm{MgCl}_{2}(8 \mathrm{mmol} / 1)$. After $15 \mathrm{~min}$ at $20^{\circ} \mathrm{C}$ the reaction was terminated by adding a boiling SDS solution. In some experiments the phosphorylated proteins were first subjected to immunoprecipitation by antireceptor antibodies.

\section{Immunoprecipitation and gel analysis}

Immunoprecipitation of insulin receptors was achieved by incubation with anti-receptor antiserum [18] at a $1: 300$ dilution for $16 \mathrm{~h}$ at $4{ }^{\circ} \mathrm{C}$ followed by an additional $4 \mathrm{~h}$ at $4^{\circ} \mathrm{C}$ with staphylococcus aureus cells (Pansorbin Calbiochem, La Jolla, Calif). The immunoprecipitates were collected by centrifugation $\left(1 \mathrm{~min}\right.$ at $2,000 \mathrm{~g}$ at $4^{\circ} \mathrm{C}$ ) and pellets were washed 3 times in $50 \mathrm{mmol} / 1$ Hepes $/ 150 \mathrm{mmol} / 1 \mathrm{NaCl}$. All samples were solubilised and boiled for $5 \mathrm{~min}$ in a solution containing $3 \%$ (w/v) SDS, $10 \%$ (vol/vol) glycerol, sodium phosphate $(10 \mathrm{mmol} / \mathrm{l})$, $0.01 \%$ bromophenol blue and $2 \%$ (vol/vol) 2-mercaptoethanol. Aliquots $(50 \mu \mathrm{l})$ were analysed by one-dimensional SDS-PAGE as described by Laemmli [19] with a $7.5 \%$ or a $5 \%$ acrylamide gel as the resolving gel. The $M_{\mathrm{r}}$ 's of the standards used were: myosin 200,$000 ; \beta$ galactosidase 116,000 ; phosphorylase B 94,000 ; bovine serum albumin 67,000 ; ovalbumin 43,000 ; carbonic anhydrase 30,000 ; soybean trypsin inhibitor 20,000 and lysozyme 14,000 . The gels were stained, dried and autoradiographed by exposition of the gels to Kodak XOmat films.

\section{Results}

\section{Immunoprecipitation of photolabelled insulin receptors}

Photoreactive insulin has been widely used to label the $\alpha$-subunit of the insulin receptor in a variety of adult tissues $[12,13]$. In adult rabbit liver, ${ }^{125}$ I-photoreactive insulin predominantly labels a $130 \mathrm{kDa}$ protein (Fig. 1, I). This protein corresponds to the $\alpha$-subunit of the insulin receptor, since its labelling is protected by an excess of unlabelled insulin (Fig. 1, J) and because it is immunoprecipitated by a serum containing anti-receptor antibodies and not by a control serum (Fig. 1, A and B). A similar $130 \mathrm{kDa}$-labelled subunit is found in the liver of new-born rabbits (Fig. 1, G) and in livers of 30-day-old (Fig. 1,E) and 20-day-old (Fig. 1, C) fetuses. These re- 

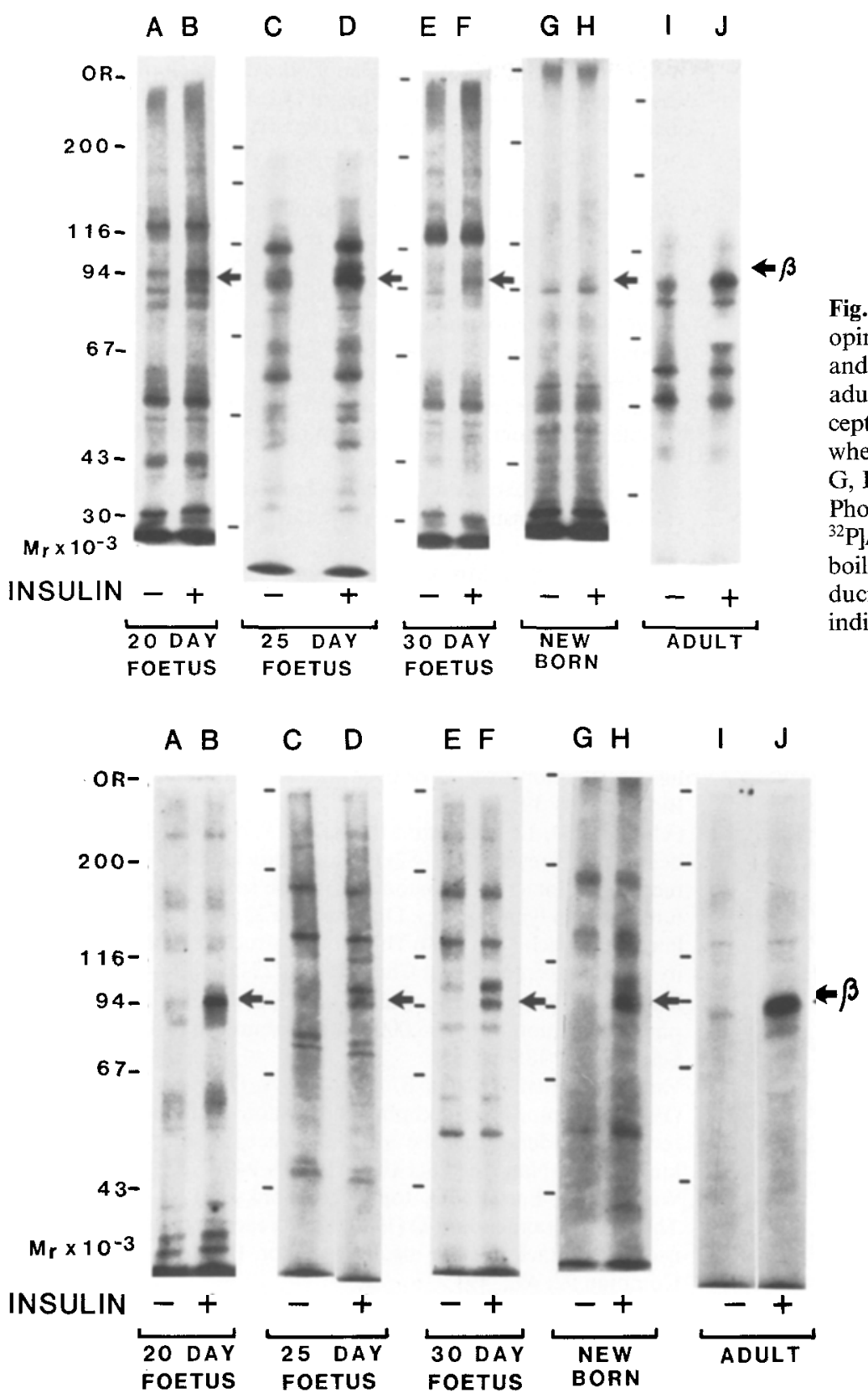

Fig.3. Phosphorylation of insulin receptors from livers of developing rabbits. Livers from 20 day-old (A, B), 25 day-old (C, D) and 30 day-old $(E, F)$ fetuses and from new born $(G, H)$ and adult $(I, J)$ rabbits were extracted and homogenised. Insulin receptors were partially purified by affinity chromatography on wheat-germ agglutinin-agarose and incubated without $(\mathrm{A}, \mathrm{C}, \mathrm{E}$, $\mathrm{G}, \mathrm{I})$ or with $(\mathrm{B}, \mathrm{D}, \mathrm{F}, \mathrm{H}, \mathrm{J}) 0.1 \mu \mathrm{mol} / \mathrm{l}$ insulin for $1 \mathrm{~h}$ at $24^{\circ} \mathrm{C}$. Phosphorylation reaction was initiated by addition of $[\gamma$ $\left.{ }^{32} \mathrm{P}\right] \mathrm{ATP}, \mathrm{Mg}^{2+}, \mathrm{Mn}^{2+}$ and stopped $15 \mathrm{~min}$ later by addition of boiling SDS. Proteins were analyzed by SDS-PAGE under reducing conditions and revealed by autoradiography. The arrow indicates the $\beta$-subunit of the insulin receptor. sults indicate that in the early stages of liver development insulin receptors are already present. The $\alpha$-subunits of these receptors have the same molecular weight as in adult tissues. They bind insulin and are recognized by antibodies that are known to react with adult insulin receptors [20].

In brown adipose tissue of adult rabbits a $130 \mathrm{kDa}$ $\alpha$-subunit is also detected (Fig. 2, E and F). The insulin receptor of this tissue has, to our knowledge, never been characterized. This receptor can also be labelled and immunoprecipitated in 30-day-old fetus (Fig. 2, C).

\section{Phosphorylation of insulin receptor}

The insulin receptor $\beta$-subunit contains a tyrosine protein kinase that is capable of self-phosphorylation stim- ulated by insulin $[15,16]$. This property can thus be used to probe the structure of the $\beta$-subunit [20] and also to investigate the functionality of the receptor, since an insulin-responsive phosphorylation requires a signal transmission from the $\alpha$-subunit (the insulin binding site) to the $\beta$-subunit (the kinase site). We have therefore partially purified insulin receptors from livers of rabbits at different developing stages, and tested whether insulin could stimulate the autophosphorylation of its receptor. Figure 3 shows that, under basal conditions (in absence of insulin), the number of phosphorylated proteins fluctuates with the age of development (Fig. 3, A, C, E, G, I). However, at all stages addition of insulin stimulates phosphorylation of a $95 \mathrm{kDa}$ protein. These results thus indicate that an insulin sensitive receptor kinase is detectable in the liver as early as day 20 of gestation. 
In brown adipose tissue an insulin-stimulated phosphorylation of the $\beta$-subunit is seen at all stages, from 20-day-old fetuses to adult animals (Fig.4). It is also worth noticing that another protein $\left(M_{r} 110 \mathrm{kDa}\right)$ is phosphorylated in the presence of insulin in 25 and 30 day-old fetuses and in new born animals (Fig. 4, D, F, $H)$. This protein has been recently identified as an endogenous substrate for the insulin receptor kinase [21].

\section{Discussion}

The emergence of hormone receptors in fetal tissues is as important as the onset of hormone secretion in determining the fetal stage at which tissues will respond to the hormone. It must, however, be recognized that the appearance of a specific insulin binding capacity is not sufficient to allow the development of insulin responsiveness of a tissue. Indeed, if the first step in insulin action is the specific recognition by the hormone of cell surface receptors, a transmembrane signalling mechanism is necessary to convey the hormonal message to the cell interior. The earliest known biological event occurring at the receptor level after insulin binding is the activation of tyrosine kinase activity contained within the $\beta$-receptor subunit and capable of autophosphorylation $[15,16]$. A functional insulin receptor will therefore be expected to consist of an $\alpha$ - $\beta$-subunit arrangement capable of binding insulin and of insulin-stimulated receptor autophosphorylation. In fetal tissues we found an immunoprecipitable receptor kinase activity as soon as insulin binding capacity is detectable. Moreover, the apparent molecular weight of $\alpha$-subunits (the insulin binding domain) and $\beta$-subunits (the tyrosine-kinase domain) were identical in fetal and adult tissues.

Although the developing rabbit has been widely used as a model for catecholamine receptor ontogenesis [22], there are only a few data concerning the development of insulin receptors in this species [4]. The present study demonstrates functional insulin receptors from day 20 of gestation to adulthood, thus indicating that maturation of operative insulin receptors is an early fetal function consistant with the early anabolic and growth effects of insulin in developing fetuses [7].

Acknowledgments. We are indebted to G. Visciano for illustration work and A. Rainaud for secretarial assistance.

\section{References}

1. Kaplan SL, Grumbach MM, Shepard TH (1972) The ontogenesis of human foetal hormones. I. Growth hormone and insulin. J Clin Invest 51: 3080-3093

2. Blazquez E, Rubalcava B, Montesano R, Orci L, Unger RH (1976) Development of insulin and glucagon binding and the adenylate cyclase response in liver membranes of the prenatal, post-natal and adult rat: evidence of glucagon "resistance". Endocrinology 98: 1014-1023
3. Devaskar SU, Ganguli S, Devaskar UP, Sperling MA (1982) Glucocorticoids and hypothyroidism modulate development of fetal lung insulin receptors. Am J Physiol 242: E384-E391

4. Ganguli S, Sinha M, Sterman B, Harris P, Sperling M (1983) Ontogeny of hepatic insulin and glucagon receptors and adenylate cyclase in rabbit. Am J Physiol 244: E624-E631

5. Warren DW, Huhtaniemi IT, Tapanainen J, Dufau M, Catt K (1984) Ontogeny of gonadotropin receptors in the fetal and neonatal rat testis. Endocrinology 114: 470-476

6. Daughaday WH, Herington AC, Phillips LS (1975) The regulation of growth by endocrines. Ann Rev Physiol 37: 211-244

7. Cooke PS, Nicoll CS (1984) Role of insulin in the growth of fetal rat tissues. Endocrinology 114: 638-643

8. Ulane RE, Graeber IE, Hansen JW, Liccini L, Cornblath M (1982) Insulin receptors in the developing fetal lung. Life Sci 31: 3017-3022

9. Vinicor F, Kieckrowski L (1982) Characterization of the hepatic receptor for insulin in the perinatal rat. Endocrinology 110: 782-790

10. Sara VR, Holl K, Misaki M, Fryklund L, Christensen N, Wetterberg $\mathrm{L}$ (1983) Ontogenesis of somatomedin and insulin receptors in the human fetus. J Clin Invest 71: 1084-1097

11. Kaplan SA, Barrett CT, Scott ML, Whitson RH (1984) Insulin receptors in fetal rabbit lung type II cells. Endocrinology 114: 2199-2204

12. Yip CC, Yeung CWT, Moule ML (1980) Photoaffinity labeling of insulin receptor proteins of liver plasma membrane preparations. Biochemistry 19: 70 76

13. Fehlmann M, Le Marchand-Brustel Y, Van Obberghen E, Brandenburg D, Freychet $P$ (1982) Photoaffinity labelling of the insulin receptor in intact rat hepatocytes, mouse soleus muscle, and cultured human lymphocytes. Diabetologia 23: 440-444

14. Pilch PF, Czech MP(1980) The subunit structure of the high affinity insulin receptor. J Biol Chem 255: 1722-1731

15. Kasuga M, Karlsson FA, Kahn CR (1982) Insulin stimulates the phosphorylation of the 95,000 dalton subunit of its own receptor. Science 215: $185-187$

16. Van Obberghen E, Rossi B, Kowalski A, Gazzano H, Ponzio G (1983) Receptor mediated phosphorylation of the hepatic insulin receptor: evidence that the Mr 95,000 receptor subunit is its own kinase. Proc Natl Acad Sci USA 80: 945-949

17. Wisher MH, Baron MD, Jones RH, Sönksen PH, Saunders DJ, Thamm P, Brandenburg D (1980) Photoreactive insulin analogues used to characterise the insulin receptor. Biochem Biophys Res Commun 92: 492-498

18. Kahn CR, Flier JS, Bar RS, Archer JA, Gorden P, Martin MM, Roth J (1976) The syndromes of insulin resistance and acanthosis nigricans: insulin-receptor disorders in man. N Engl J Med 294: 739-745

19. Laemmli UK (1970) Cleavage of structural proteins during the assembly of the head of bacteriophage T4. Nature (London) 227: 680-685

20. Chvatchko Y, Gazzano H, Van Obberghen E, Fehlmann M (1984) Subunit arrangement of insulin receptors in hepatoma cells. Mol Cell Endocrinol 36: 59-65

21. Sadoul JL, Peyron JF, Ballotti R, Debant A, Fehlmann M, Van Obberghen E (1985) Identification of a cellular 110,000 Da protein substrate for the insulin receptor kinase. Biochem $J$ 227: $887-892$

22. Whitsett JA, Manton MA, Darovec-Beckerman C, Adams KG, Hoore JJ (1981) $\beta$-Adrenergic receptors in the developing rabbit lung. Am J Physiol 240: E351-E357

Received: 28 January 1985

and in revised form: 20 May 1985

Dr. M.Fehlmann

INSERM U 145

Faculté de Médecine (Pasteur)

F-06034 Nice, Cédex

France 